\title{
EXAMINATION OF CRP (C-Reactive Protein) IN OBESE TEENAGERS IN SMA MUHAMMADIYAH 02 MEDAN
}

\author{
Ice Ratnalela Siregar \\ Dosen Jurusan Analis Kesehatan Poltekkes Medan
}

\begin{abstract}
C-Reactive Protein (CRP) is one of the acute phase proteins present in normal serum in very little concentrations synthesized in the liver that play a role in inflammation. Obesity is a state of increase in body fat (adipocyte cells) in which adipocytes will try to maintain energy by releasing proinflammatory cytokines one of them interleukin 6 (IL-6), IL-6 release will induce CRP production in the liver. CRP examination on obese students in SMA Muhammadiyah 02 Medan.This research was conducted descriptively by Latex Aglutination method. This research was conducted at the Laboratory of Poltekkes Kemenkes Medan Health Analyst Department in May 2017 after sampling of students in SMA Muhammadiyah 02 Medan. The population of this research is 30 people of total population of 30 samples.Based on the research that has been done, the result of positive CRP examination is 18 percentage samples are $60 \%$ and 12 percent negative sample $40 \%$. Based on sex, the result of positive CRP examination were 13 samples of female sex, $44 \%$ and 5 positive samples of male were $17 \%$. Suggested on obese students to regularly exercise and live healthy with healthy foods also to avoid disease.
\end{abstract}

Keywords : CRP, Obesity

\section{PENDAHULUAN}

\subsection{Latar Belakang}

Kondisi sosial ekonomi yang semakin meningkat di negara maju dan beberapa negara berkembang memungkinkan terjadinya perubahan gaya hidup. Salah satunya ialah perubahan pola makan dengan diet rendah karbohidrat dan tinggi lemak sehingga dapat menyebabkan perubahan gizi yang tidak seimbang. Obesitas umumnya menyebabkan akumulasi lemak pada daerah subkutan dan jaringan lainnya. Peningkatan prevalensi obesitas ini ternyata berkaitan erat dengan meningkatnya prevalensi kejadian sindrom metabolik. Peningkatan kejadian sindrom metabolik sejalan dengan peningkatan lemak subkutan. CRP merupakan protein yang disintesis di hati sebagai responden terhadap rangsangan pada saat inflamasi fase akut (Gansareng dkk, 2015).

Berdasarkan data Global Nutrition Report, sebanyak $10 \%$ penduduk di Indonesia mengalami berat badan berlebih (overweight) dan sebanyak 2\% mengalami obesitas. Data Riskesdas (Riset Kesehatan Dasar) Depkes RI tahun 2013 menunjukkan bahwa prevalensi obesitas sebesar $15,4 \%$ dan overweight sebesar $13,5 \%$. Jika prevalensi obesitas dan overweight digabungkan, maka prevalensi penduduk Indonesia yang mengalami kelebihan berat badan sebesar 28,9\%. Ini adalah jumlah yang cukup besar karena lebih dari seperempat atau hampir sepertiga penduduk Indonesia mengalami kelebihan berat badan.

Overweight dan obesitas bisa diketahui dengan mengukur indeks massa tubuh (IMT), yaitu dengan mengukur berat badan dan tinggi badan. IMT dihitung dengan membagi berat badan (dalam kilogram) dengan kuadrat tinggi badan (dalam meter). Indeks massa tubuh ini adalah indikator yang paling sering digunakan dan praktis untuk mengukur tingkat populasi overweight dan obesitas.

Berdasarkan klasifikasi Indeks Massa Tubuh (IMT) menurut Asia Pasifik seseorang dikatakan overweight jika memiliki IMT 23-24,9 dan seseorang dikatakan obesitas jika memiliki IMT $\geq 25$. Sedangkan menurut Depkes RI seseorang dikategorikan overweight jika IMT $>25$ dan obesitas jika IMT $\geq 27,0$. Menurut salah satu penelitian, setiap kenaikan berat badan satu unit IMT, dapat meningkatkan 4-5\% mortalitas penyakit jantung koroner (Sugiritama dkk,2015).

Obesitas merupakan gangguan komposisi lemak tubuh akibat peningkatan jumlah lemak. Sebagian besar lemak yang di peroleh dari makanan di simpan dalam bentuk trigliserida dalam jaringan adiposa/lemak.Peningkatan trigliserida akan menyebabkan sel adiposity / lemak berusaha mempertahankan keseimbangan energi dengan melepaskan sitokin-sitokin proinflamasi seperti interleukin-6, tumor necrosis faktor- $\alpha$ (TNF- $\alpha$ ) dan monocyte chemotactic protein-1 (MCP-1). Pelepasan IL-6 ini akan menginduksi C-Reaktive Protein (CRP) di hati(Melda dkk,2013). Peningkatan jaringan adiposa ini akan mengakibatkan peningkatan sekresi IL-6, kondisi ini mengakibatkan inflamasi sistemik ringan yang merangsang sintesa CRP di hati. Dengan demikian penurunan berat badan dapat mengurangi jaringan adiposa sehingga sekresi sitokin proinflamasi berkurang sehingga induksi produksi CRP juga berkurang maka resistensi insulin dan resiko penyakit kardiovaskuler jadi menurun (Budiman,2014). 
Komponen dasar yang harus di evaluasi pada pasien obesitas salah satunya adalah pemeriksaan medis laboraturium. Pemeriksaan

laboraturium yang di kerjakan adalah profil lipid, kadar glukosa dan C-reactive protein (CRP) Soegih,2009).

Sekolah Menengah Atas (SMA) Muhammadiyah 02 yang terletak di Jl. Abdul Hakim Pasar 1 Kel.Tanjung Sari,Kecamatan Medan Selayang. Di sekolah ini terdiri dari 11 orang guru, 3 pegawai dan ruang kelas diantaranya kelas I (6 ruangan), II (6 ruangan), dan kelas III (5 ruangan),setiap ruangan terdiri dari \pm 40 orang siswa/siswi. Jika dirata-ratakan jumlah siswa/siswi sebanyak 680 orang.

Penelitian yang dilakukan oleh mahasiswa Universitas Diponegoro di SMA Negeri 2 Semarang adalah $7,9 \%$ remaja yang mengalami obesitas. Prevalensi sindrom metabolik pada remaja obesitas adalah 15,2\%. Dalam penelitian ini lingkar pinggang terbukti merupakan faktor risiko terhadap peningkatan kadar CRP(Mayasari,2014).

Pada penelitian yang dilakukan di Universitas Hassanudin menunjukkan bahwa dari 40 orang jumlah mahasiswa dengan umur 17-20 tahun yang memiliki Indeks Masa Tubuh kategori obesitas mempunyai kadar CRP berisiko tinggi sebesar $35,0 \%$ sedangkan berisiko sedang sebesar 42,5\%(Hanum dkk,2013).

Obesitas dapat terjadi pada siapa saja termasuk siswa/siswi di SMA Muhammadiyah 02 Medan, karena pola makan yang tidak sehat dan suka ngemil jajanan yang ada di lingkungan sekolah kemudian tidak di barengi olahraga yang rutin,ini memungkinkan menyebabkan kegemukkan pada remaja tersebut.

Berdasarkan latar belakang di atas sehingga penulis ingin melakukan pemeriksaan CRP pada siswa/siswi obesitas di SMA Muhammadiyah 02 Medan.

\subsection{Rumusan Masalah}

Berdasarkan latar belakang tersebut, maka penulis tertarik untuk melakukan Pemeriksaan CRP ( $C$ reactive protein) terhadap siswa/siswi SMA Muhammadiyah 02 Medan yang obesitas.

\subsection{Tujuan Penelitian}

\subsubsection{Tujuan Umum}

Untuk mengetahui CRP pada remaja (siswa-siswi) yang obesitas

di SMA Muhammadiyah 02 Medan.

\subsubsection{Tujuan Khusus}

Untuk menentukan CRP pada remaja (siswa-siswi) obesitas di SMA Muhammadi yah 02 Medan.

\subsection{Manfaat Penelitian}

1. Untuk mengetahui CRP dalam darah yang disebabkan oleh penyakit sistem metabolik yaitu obesitas.

2. Untuk informasi klinis bagi remaja yang obesitas guna menghindari berat badan yang berlebihan dan mengurangi penyakit yang disebabkan oleh sistem metabolik.
3. Sebagai sumber acuan yang dapat digunakan untuk penelitian selanjutnya.

\section{TINJAUAN PUSTAKA}

\subsection{Obesitas}

Obesitas yaitusuatu kelainan atau penyakit yang ditandai dengan penimbunan jaringan lemak tubuh secara berlebihan. Ini merupakan salah satu problem kesehatan masyarakat yang mempunyai dampak yang cukup besar bagi orang-orang tertentu yang mengalaminya. Baik dari segi kosmetika, estetika, yang lebih banyak dikaitkan dengan penampilan seseorang, dan ada juga dari segi medis. Obesitas menjadi salah satu faktor risiko bagi timbulnya beberapa penyakit tertentu yang kadang-kadang berakibat fatal jika tidak ditanggulangi secara dini. Obesitas menggambarkan suatu keadaan tertimbunnya lemak dalam tubuh sebagai akibat berlebihnya asupan makanan. Secara klinis seseorang dinyatakan mengalami obesitas bila terdapat kelebihan berat badan $15 \%$ atau lebih dari berat badan idealnya. Pada pria muda normal, rata-rata lemak tubuhnya adalah $12 \%$, sedangkan pada wanita muda sekitar $26 \%$. Pria yang memiliki lemak tubuh lebih dari $20 \%$ dari berat tubuh totalnya dinyatakan obesitas. Sementara itu, wanita baru dinyatakan obesitas bila lemak tubuhnya melebihi $30 \%$ dari berat total tubuhnya. Perbedaan ini terjadi karena metabolisme pada wanita lebih lambat dari pada pria. Pada wanita lemak biasa disimpan di bagian pinggang, paha dan pria cenderung di perut. Semakin cepat metabolisme tubuh bekerja semakin rendah pula risiko obesitas (Misnadiarly, 2010).

Selain itu ada juga dikenal obesitas hipertropik (hypertropicobe (sity). Yang diakibatkan oleh meningkatnya kandungan lipid adiposit. Obesitas hipertropik pada umumnya terjadi pada orang dewasa (Rimbawan dkk,2004).

Obesitas dan over weight adalah dua istilah yang sering digunakan untuk menyatakan adanya kelebihan berat badan. Kedua istilah ini sebenarnya mempunyai pengertian yang berbeda. Obesitas didefinisikan sebagai suatu kelainan atau penyakit yang ditandai dengan penimbunan jaringan lemak tubuh secara berlebihan. Overweight adalah kelebihan berat badan disbanding dengan berat badan ideal yang disebabkan oleh penimbunan jaringan lemak atau nonlemak, misalnya pada seorang atlet binaragawan, kelebihan berat badan dapat disebabakan oleh hipertrofil (Purnamawati,2009).

\subsubsection{Indeks Massa Tubuh (IMT)}

Salah satu pengukuran obesitas adalah dengan menggunakan Indeks Massa Tubuh (IMT). IMT adalah nilai yang diambil dari perhitungan Antara berat badan (BB) dan tinggi badan (TB) seseorang. IMT dipercayai dapat menjadi indikator atau menggambarkan kadar adipositas dalam tubuh seseorang. IMT tidak mengukur lemak tubuh secara langsung, tetapi penelitian menunjukkan bahwa IMT berkorelasi dengan pengukuran 
secara langsung lemak tubuh seperti underwater weighing dan dual energy $x$-ray absorbtiometry/Gansareng dkk,2015).

Indeks massa tubuh (IMT) dihitung dengan cara membagi berat tubuh $(\mathrm{kg})$ dengan kuadrat tinggi tubuh (m).

$$
\mathbf{I M T}=\quad \mathrm{BB}(\mathrm{kg})
$$

Klasifikasi IMT yang digunakan pada penelitian ini berdasarkan klasifikasi IMT dari Depkes RI yaitu:

\subsection{Kerangka Konsep}

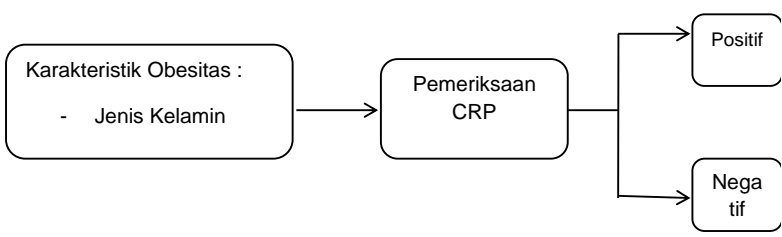

\subsection{Definisi Operasional}

1. Karakteristik obesitas adalah suatu keadaan kelebihan berat badan tubuh akibat tertimbunnya lemak

2. Jenis kelamin adalah perbedaan laki-laki dan perempuan penderita obesitas.

3. Pemeriksaan CRP adalah salah satu protein fase akut yang terdapat dalam serum normal .

4. Positif adalah interpre

itasi hasil yang diukur dengan melihat terjadinya aglutinasi

5. Negatif adalah interpretasi hasil yang diukur dengan melihat ada tidaknya aglutinasi.

\section{METODE PENELITIAN}

\subsection{Jenis dan Desain Penelitian}

Jenis dan desain penelitian yang dilakukan adalah metode deskriptif yaitu dengan melakukan pemeriksaan CRP pada siswa/siswi obesitas di SMA Muhammadiyah 02 Medan.

\subsection{Lokasi dan Waktu Penelitian}

\subsubsection{Lokasi Penelitian}

Penelitian dilakukan di Laboraturium Imunologi / Serologi di Poltekkes Kemenkes Jurusan Analis Kesehatan Jl. Williem Iskandar Pasar V Barat No.6 Medan.

\subsubsection{Waktu Penelitian}

Waktu penelitian dilakukan sejak bulan Maret-Juni 2017 di Poltekkes Kemenkes Medan Jurusan Analis Kesehatan.

\subsection{Populasi dan Sampel Penelitian}

\subsubsection{Populasi Penelitian}

Populasi penelitian adalah seluruh siswa / siswi obesitas di SMAMuhamma diyah 02 Medan Kelas I dan II.

\subsubsection{Sampel Penelitian}

Seluruh siswa / siswii kelas I dan II sebanyak 30 orang di SMA Muhammadiyah 02 Medan (total populasi).

\subsection{Jenis dan Cara Pengumpulan Data}

\subsubsection{Jenis Pengumpulan Data}

Jenis data adalah data primer yaitu data yang langsung diperoleh dengan cara pemeriksaan CRP secara kualitatif pada siswa / siswi obesitas di SMA Muhamma diyah 02 Medan.

\subsubsection{Metode Penelitian}

Metode pemeriksaan yang digunakan adalah Latex Aglutinasi.

\subsection{Bahan dan Reagensia \\ 1.5.1. Bahan}

Bahan yang digunakan adalah serum siswa/siswi obesitas di SMA Muhammadiyah 02 Medan.

Cara Pengambilan Bahan:

1. Pasang torniquit/pengebat padalengan atas, kemudian raba pembuluh darah vena yang akan ditusuk.

2. Bersihkan vena dengan swap alkohol dan biarkan kering.

3. Kemudian tusuk vena menggunakan spuit dengan diameter $45^{\circ}$

4. Setelah darah masuk ke spuit, tarik spuit secara perlahan sampai dirasa darah telah cukup.

5. Kemudian lepas tourniquit, tarik secara perlahan jarum dari vena kemudian letakkan kapas kering dengan cara ditekkan perlahan.

6. Setelah itu plaster bekas tusukkan.

7. Kemudian masukkan darah pada tabung melalui dinding tabung.

8. Diamkan selama 5 menit sampai darah membeku, kemudian sentrifugei selama 10 menit dengan kecepatan $3600 \mathrm{rpm}$.

9. Kemudian perhatikan sampel tersebut apakah terjadi hemolisis atau tidak. Apabila terjadi hemolisis maka harus dilakukan pengulangan.

10. Pisahkan serum dengan sel darah. Dan lanjut untuk melakukan pemeriksaan (Gandasoebrata, 2007).

1.6. Reagenia

1. CRP Latex Reagen

2. CRP kontrol serum positif

3. CRP kontrol serum negative

\subsection{Prosedur Kerja}

1. Pipet serum sebanyak $20 \mu \mathrm{l}$, kemudian letakkan pada permukaan slide.

2. Tambahkan $20 \mu \mathrm{l}$ Latex reagen dan homogenkan.

3. Letakkan slide pada rotator dalam waktu 2-3 menit. 
4. Amati apakah terjadi aglutinasi atau tidak.

5. Baca hasil dan laporkan.

\subsection{Interpretasi Hasil}

Positif (+) : adanya aglutinasi.

Negatif (-) : tidak adanya aglutinasi (Gandasoebrata, 2007).

\subsection{Analisa Data}

Pengelolahan data dalam penelitian ini dilakukan secara manual dengan menggunakan tabel distribusi frekuensi dan dibahas sesuai daftar pustaka yang ada.

\section{HASIL DAN PEMBAHASAN}

\subsection{Hasil Penelitian}

Hasil penelitian yang telah dilakukan terhadap 30 sampel darah siswa/siswi SMA Muhammadiyah 02 Medan yang obesitas dan diperiksa di Laboraturium Imunulogi/Serologi Poltekkes Kemenkes Jurusan Analis Kesehatan pada bulan Mei 2017 dapat dilihat pada tabel berikut:

\subsection{Persentase Data Siswa/Siswi yang Obesitas}

4.2.1 Persentase Data Siswa/Siswi yang Obesitas dari 30 sampel terdapat 18 sampel yang positif.

\section{Hasil Pemeriksaan CRP}

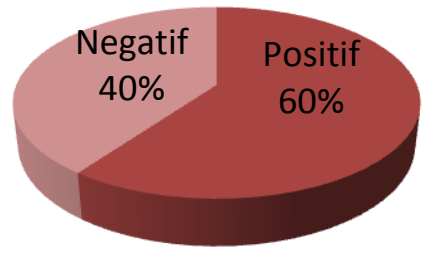

Pada diagram pie dapat dilihat bahwa pada siswa/siswi di SMA Muhammadiyah 02 Medan yang obesitas memiliki persentase positif $60 \%$ dan negatif $40 \%$.

4.2.2 Persentase Data Siswa/Siswi obesitas yang positif berdasarkan jenis kelamin.

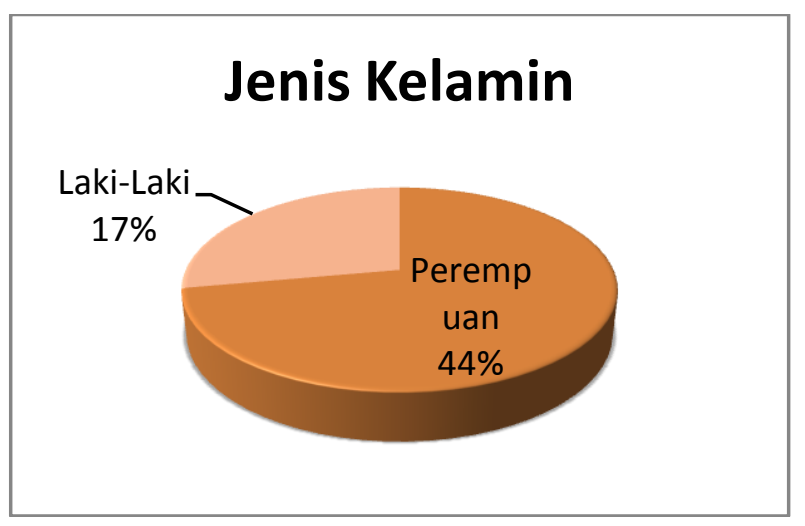

Pada diagram pie dapat dilihat bahwa pada siswa/siswi di SMA Muhammadiyah 02 Medan yang obesitas persentase berdasarkan jenis kelamin pada perempuan $44 \%$ dan laki-laki $17 \%$.

\subsection{Pembahasan}

Berdasarkan penelitian yang dilakukan terhadap 30 sampel darah dari siswa/siswi yang obesitas di SMA Muhammadiyah 02 Medan ditemukan hasil pemeriksaan CRP yang positif sebanyak 18 orang dan yang negatif sebanyak 12 orang. Berbagai mekanisme akan menimbulkan peningkatan CRP, salah satunya obesitas, akibat kelebihan jaringan adipose akan menghasilkan sitokin yang akan menimbulkan reaksi inflamasi (Soegih $\mathrm{dkk}, 2009)$. Sitokin yang dapat dihasilkan jaringan adiposa yaitu sitokin-sitokin yang memiliki efek seperti organ endokrin. Beberapa diantaranya yaitu leptin, adiponektin, interleukin-6 dan TNF- $\alpha$ (Hanum dkk, 2013). Penurunan berat badan dengan hidup sehat dan rajin berolahraga dapat menurunkan resiko peningkatan CRP yang biasanya menyebabkan jantung koroner dan semakin banyak lemak dibuang semakin baik pula kadar CRP (Nurrahamani, 2012).

Pada masa remaja adalah masa terjadinya perubahan dramatis yang berhubungan dengan perubahan humoral,kognitif,dan emosional. Oleh sebab itu pada remaja perubahan berat badan dapat mudah terjadi, karena kondisi ekonomi yang yang semakin modern,pola makan yang tidak sehat dan aktifitas yang banyak sehingga tidak bisa untuk berolahraga. Ini menyebabkan terjadinya penumpukkan lemak yang berujung obesitas (Hanum $\mathrm{dkk}, 2013)$

\section{KESIMPULAN DAN SARAN}

\subsection{Kesimpulan}

Dari hasil penelitian yang telah dilakukan pada siswa/siswi yang obesitas di SMA Muhammadiyah 02 Medan di Laboraturium Politeknik Kesehatan Kemenkes Medan Jurusan Analis Kesehatan dapat disimpulkan sebagai berikut :

1. Dari 30 sampel darah yang di dilakukan pemeriksaan CRP ada 18 sampel yang positif dan 12 sampel yang negatif.

2. Berdasarkan jenis kelamin dari 18 sampel yang positif terdapat 13 sampel berjenis kelamin perempuan dan 5 sampel berjenis kelamin laki-laki.

\subsection{Saran}

1. Bagi penderita obesitas sebaiknya melakukan terapi dengan melakukan aktivitas-aktivitas yang dapat mengurangi berat badan, contohnya berolahraga, hidup sehat, dan mengurangi untuk mengkonsumsi makanan yang mengandung lemak berlebih dan makanan siap saji.

2. Bagi peneliti selanjutnya agar dapat meneliti dengan jumlah sampel yang lebih 
besar dan dijadikan bacaan informasi ilmiah untuk penelitian selanjutnya.

\section{DAFTAR PUSTAKA}

Arnadidkk, 2006.Ilmu Penyakit Dalam .Jakarta :Departemen Ilmu Penyakit Dalam FK UI.

Budiman.2014.Pengaruh Modifikasi Pola Hidup Dengan Atau Tanpa Metformin Terhadap Kadar CReaktif Protein Pada Obesitas.

http://repository.usu.ac.id/ bitstream/123456789/4033/9/5/Chapter\%20I.pdf. Diakses pada tanggal 4 Oktober 2016.

Cahyono, B. 2008.Gaya Hidup Dan Penyakit Modern. Jogjakarta: KANISIUS

Fever, J. 2007. Pedoman Pemeriksaan Laboraturium Dan Diagnostik. Jakarta : EGC

Gandasoebrata, R. 2007. Penuntun Laboraturium Klinik. Jakarta : PT. Dian Rakyat

Ganserang, Deril. 2015. Hubungan Antara Ketebalan Lemak Dan Kadar C-Reactive Protein.

http://ejournal.unsrat.ac.id/index.php/ebiomedik/article/vie w/.Diakses pada tanggal 5 Desember 2016.

Handojo, Indro.2004.

Imunisasi Terapan Pada Beberapa Penyakit Infeksi. Surabaya: Airlangga University Press.

Hanum, 2013. Obesitas Dan HsCRPPada Remaja Mahasiswa Baru Di Universitas Hassanuddin. http://pasac.unhas.ac.id/jurnal/files/pdf. Diakses pada tanggal 8 Oktober 2016.

Khasanah, Nur. 2012. Penyakit degenerative Akibat Pola Makan.Jogjakarta :Laksana.

Mayasari, Santi. 2014. Densitas Energi Makanan Dan Lingkar Pinggang Sebagai Faktor Risiko Peningkatan Kadar C-Reactive Protein (CRP) Pada Remaja Obesitas Dengan Sindrom Metabolik. http://eprints.undip.ac.id/pdf. Diakses pada tanggal 16 November 2016.
Mayulu, Nelly. 2015. Hubungan Lingkar Pinggang Dengan Kadar HsCRP.http://ejournal.unsrat.ac.id.index.php/ebio medik/article/view.Diakses pada tanggal 4 Januari 2017.

Melda.2013. Hubungan Kadar Trigliserida Darah Dengan Kadar HsCRP Pada Remaja Obes.

http://ejournal.unsrat.ac.id.index.php/ebiomedik/article/vie w/3647. Diakses pada tangga 15 Desember 2016.

Misnadiarly, 2010.Obesitas Sebagai Faktor Resiko Beberapa Penyakit. Jakarta :Pustaka Obor Populer.

Profil SMA MUHAMMADIYAH 02 Jl. Abdul Hakim Pasar 1 Kel.Tanjung Sari, Kec. Medan.

Purnamawati, Irene. 2009. Prevalens Obesitas Pada Anak Taman Kanak-Kanak di Kelurahan Cikini, Kecamatan Menteng. http://lib.ac.id/file/122846S09039fk. Diakses pada tanggal 19 April 2017.

Rimbawan,2004. Indeks Glikemik Pangan.Jakarta :Penabur Swadaya.

Russel, M. 2011. Bebas Dari 6 Penyakit Paling Mamatikan. Jogjakarta : Media Presindo

Silalahi, dkk.2012. Penilaian Kadar HsCRP Pada Subjek Sindrom Metabolik Dan Obesitas. http://repository.usu.ac.id/bitsteram.Diakses 3 Maret 2017. 